Studia Anglica Posnaniensia 50/2-3, 2015

doi: $10.1515 /$ stap-2015-0023

\title{
LITERARINESS AND RACIAL CONSCIOUSNESS IN PAULE MARSHALL'S MEMOIR TRIANGULAR ROAD AND GLORIA NAYLOR'S FICTIONALIZED MEMOIR 1996
}

\author{
AGNIESZKA ŁOBODZIEC
}

University of Zielona Góra

\begin{abstract}
Black American women writers were side-lined by the literary canon as recently as the 1980s. Today, as a result of their agency, a distinct literary tradition that bears witness to black women's particular expressiveness is recognized. Bernard Bell observes that the defining features common to most literary works by black American women are a focus on racist oppression, black female protagonists, the pursuit of demarginalization, women's bonding, women's relationship with the community, the power of emotions, and black female language. Although these elements refer predominantly to novels, they are also present in Paule Marshall's memoir Triangular Road (2009) and Gloria Naylor's fictionalized memoir 1996 (2005). Moreover, the two works are fitting examples of racial art, the point of departure of which, according to Black Arts Movement advocates, should be the black experience. Actually, since through memoirs the authors offer significant insights into themselves, the genre seems closer to this objective of racial art than novels. At the same time, taking into consideration the intricate plot structures, vivid images, and emotional intensity, their memoirs evidence the quality of literariness i.e., in formalist terms, the set of features that distinguish texts from non-literary ones, for instance, reports, articles, text books, and encyclopaedic biographical entries. Moreover, Marshall and Naylor utilize creative imagination incorporating fabulation, stories within stories, and people or events they have never personally encountered, which dramatizes and intensifies the experiences they relate. In Marshall's memoir, the fictitious elements are discernable when she imagines the historical past. Naylor demarks imagined narrative passages with separate sections that intertwine with those based upon her actual life experience.
\end{abstract}

Key words: black experience, literariness, emotions, imagination, memory

\section{The significance of racial experience and racial consciousness}

Paule Marshall's memoir Triangular Road and Gloria Naylor's fictionalized memoir 1996 represent black women's particular literary tradition. The works 
possess a number of defining features characteristic of traditional black American women writing. Most apparent is the centrality of black female protagonists (Bell 2004: 137). At the beginning of their narratives, the writers formulate their subject positions as black American women. ${ }^{1}$ Marshall depicts herself as a politically conscious black American novelist coerced to confront the white dominated power structure, personified by a blond-haired, blue-eyed female official of The United States Department of State. The agent interviewed her after the distinguished black American poet Langston Hughes, who had received a State Department literary grant, asked her to accompany him on his research tour through Europe. Marshall was most perplexed by the white female's allusive reference to her political and social engagement: "Seems you've been fairly active" (2005: 8). Gloria Naylor, in turn, starts off with an account of her parents who taught her that "[y]our race or your gender was no excuse for not succeeding ... that no one was better than we were just because of skin color" (2009: 5). Both Marshall and Naylor express racial and gender consciousness.

Another characteristic of black women's writing is their focus on racial oppression (Bell 2004: 137). The two writers make a number of references to slavery, black disfranchisement, racism, and the white establishment. Marshall's historical reconstructions are more detailed, while Naylor mentions slavery only in

1 Paule Marshall is a Black American novelist of Barbadian origin, born in 1929 in Brooklyn, New York. Recipient of a Guggenheim Fellowship in 1960, the National Institute of Arts Award in 1961, the Rosenthal Award in 1962, the Columbus Foundation American Book Award in 1984, the American Book Award in 1984 and a MacArthur Foundation Fellowship in 1992. She is the author of five novels (Brown Girl, Brownstones (1959), The Chosen Place, the Timeless People (1969), Praisesong for the Widow (Putnam, 1983), Daughters (1991), The Fisher King: A Novel (2001)), a collection of short novels Soul Clap Hands and Sing (1961), two collections of short stories (Reena and Other Stories (1983), Merle: A Novella, and Other Stories (1985) (Bell 2004: 263-264) and her memoir (Triangular Road: A Memoir (2009)). As noted in her memoir, in 1965 the distinguished black American poet Langston Hughes chose her to accompany him on a European tour financed by the US State Department. A recurring theme in her literary works is the rediscovery of tripartite identity regarding The United States, the West Indies, and Africa by way of race and gender oriented negotiation of the three cultural and geopolitical spaces.

Gloria Naylor is a Black novelist and educator. She was born in 1950 in Harlem, New York She is a recipient of the National Endowment of the Arts fellowship (1985) and a Guggenheim fellowship (1988). She lectured under a United States Information Agency exchange program in India in 1985. Naylor was a writer-in-residence at the Cummington Community of Arts (1983) and served as visiting professor at the following universities: George Washington University (1983-1984), University of Pennsylvania (1986), New York University (Spring 1986), Princeton (1986-1987), Boston University (1987), Brandeis University (1988), and Cornell (1988). She has authored several novels: The Women of Brewster Place (1982), Linden Hills (1985), Mama Day (1988) (Macmillan 1998: 504) and The Men of Brewster Place (1999) In 2005 she published a fictionalized memoir titled 1996. Through her fictional characters, she reconstructs possible demarginalizing measures to challenge racial and sexual oppression as well as class discrimination. 
the context of the black literary tradition's development, emphasizing the formidable challenge black writers confronted "when it was illegal to teach slaves to read or write" (2009: 7). Marshall painstakingly relates the inhumanity of the Middle Passage, auction blocks, and the tobacco plantation system. She is outraged by the current disneyfication of former slave plantations and is disconcerted by the attitude of her fifty-year-old New York Jewish editor, who is as thrilled about an upcoming plantation tour as if she had "just been promised a trip to Disneyland" (55). With regard to contemporary manifestations of racism, Marshall sometimes alludes to today's racially stratified American society permeated by notions of black inferiority, high black unemployment rates, and targeted surveillance. Naylor highlights racial profiling and racial surveillance, reconstructing her own victimization by surveillance as an experience of racist oppression. She discovers a National Security Agency Watch List, with a roster of "[e]very black, Latino, and Asian writer who has had any press coverage" (33).

Naylor's and Marshall's emphasis on racial consciousness and racial oppression is related to another leitmotif characteristic of black women's writing, mainly the relationship of black women to the black community. The two women's personal experiences are depicted as representative of collective ones. The two works under consideration exemplify racial art whose point of departure, according to Black Aesthetic Movement advocates, should be the black experience. One of the key founders of the movement, Stephen Henderson, defines this racial artistic perspective as 'saturation,' which is "the communication of blackness in a given situation and a sense of fidelity to the observed and intuited truth of the black experience" (Matthews 1998: 75). Memoirs, therefore, could be regarded as being most reliable in pursuance of a black experience-oriented racial art objective than any other genre, apart from autobiography, in that narratives comprising memoirs are reconstructions of both the authors' racial experiences and also the broader black community's experience.

\section{The pursuit of demarginalization}

Not only do black American women writers stress the multifarious nature of racial oppression but they also portray demarginalization pursuits, "spiritual journeys from victimization to the realization of personal autonomy or creativity" (Bell 2004: 137). Such depictions of black women by black women writers are creative oppositional manifestations to stereotypical representations of black female characters and the black community in canonical literature.

Until the 1940s; black women in both Anglo- and Afro-American literature have been usually assigned stereotyped roles - their images being a context for some other major dilemma or problem the society cannot resolve. Throughout the novels of the slavery and reconstruction periods, Anglo-American literature, particularly 
southern white literature, fashioned an image of the black woman intended to further create submission, conflict between the black man and woman, and importantly, a dumping ground for those female functions a basically Puritan society could not confront. (Christian 1985: 2)

Initially, in challenging white purveyance of negative, derogating black images, black women writers began to construct "women-centered communities [as] defenses against sexism and racism, in other words against the abuses that are inflicted on black women" (Christian 1993: 120). Simultaneously, the writers developed a female-centered approach relative to the broader black community.

Correspondingly, politically speaking, Marshall and Naylor give homage to various individual activists, organizations, and black liberation movements. Marshall acknowledges the contributions of W.E.B. DuBois, Marcus Garvey, and the Civil Rights Movement to the struggle for racial equality in America along with the Caribbean Bussa's rebellion and activist Nanny Griggs' struggles against Caribbean slavery. Naylor acknowledges the Civil Rights Movement and the Million Man March. The inclusion of these references in their writings exhibits a feature common to black women's literature observed by Katie Geneva Canon (2003: 63), who notes: "As creators of literature these women are not formally historians, sociologists, or theologians, but the patterns and themes in their writings are reflective of historical facts, sociological realities, and religious convictions that lie behind the ethos and ethics of the Black community."

At a more personal level, both writers present their education and writing as salvific and socially uplifting. Marshall remembers her disbelief and excitation that Langston Hughes had selected her as an accompanying writer: "I stood dumbstruck for the longest time. Langston Hughes! None other than the poet laureate of black America has chosen me to accompany him on a cultural tour of Europe! Me, a mere fledging of a writer, with only one novel and a collection of stories published to date!" (2-3). This honour bolstered her self-confidence. The act of composing a memoir also brought rediscovery of her "tripartite self" (163), a fusion of African, Caribbean, and Black American ancestry, which she became aware of particularly in Barbados where she researched her familial history that she would later incorporate into her novels. She would become not only a widely read but also acclaimed black writer, who received a Guggenheim Award and grants from the Rockefeller and Ford Foundations and the Fulbright program. In Naylor's case, writing also led to national recognition after receiving the National Book Award for her first novel The Women of Brewster Place. In a subsequent novel, entitled 1996 she presents writing as a vehicle for self-expression. As an adolescent, she was silent and secretive. Her mother encouraged her to write her withheld thoughts and feelings in a diary. Thereafter up until today, she considers writing to be therapeutic. This viewpoint is observable in the first words of her 
fictionalized memoir, where she conveys her disquiet towards contemporary surveillance. "I didn't want to tell this story. It's going to take courage. Perhaps more courage than I possess, but they've left me no alternatives. I am in a battle for my mind. If I stop now, they'll have won, and I will lose myself' (3). In an interview with the black American commentator Ed Gordon, Gloria Naylor explains her objective in writing 1996,

\begin{abstract}
Since many of these things did happen to the real Gloria Naylor, by using myself as a protagonist, I was able to have the book act partly as a catharsis. Basically, what 1996 is about, it's about our loss of privacy in this country that the government has moved well beyond just the simple following of people, and the tapping of their phones. But they now have technology that is able to decode the brain patterns, and to detect what people are actually thinking. And they have another technology called microwave hearing, where they can actually input words into your head, bypassing your ears. Now, these are both, both of these technologies are documented, and people have patents for part of the process. So, what I wanted to do in 1996 was to say to my fellow Americans is that we have to be vigilant about any attacks on our civil liberties, even innocuous attacks, because they can snowball and lead to other things. (Gordon 2006)
\end{abstract}

While expressing their individual experiences, black women writers also seek to employ a language specific to black women, another characteristic feature of black American women's literature (Bell 2004: 137). Actually, Naylor does not describe this endeavour outright. She only mentions her attempt to find the appropriate words that accurately convey what she wants to express. Marshall, on the other hand, recalls that the inspiration for her literary artistry was the distinctive language spoken by black women who gathered in her mother's kitchen: "What I loved most were the sayings and Bajan proverbs that embellished their endless talk" (87). She also remembers the women as "skillful raconteurs ... superlative talkers and master story tellers" (88), further recollecting that "I couldn't have known it at the time, but I had my first lessons in the art and craft of writing while being forced to listen to Adriana [Marshall's mother] and her friends in the kitchen at 501 Hancock" (89). The influence of the women's mode of storytelling on Marshall's memoir Triangular Road is manifested by the book's structure. Her memoir also serves as an instrument of self-projection by way of which Marshall demarks the development of her literary artistry, and the significant role Bajan women's expressiveness played in the process.

\title{
3. Memoirs and literariness
}

The storytelling modes in both memoirs render the texts more literary than documentary. Paule Marshall relates several stories within the larger story of her re- 
discovery of tripartite identity. As a point of departure, she recounts the circumstances related to the European tour with Langston Hughes that enhanced both her sense of self-esteem and self-confidence as a writer. Thereafter, she moves on to three following chapters, whose titles are structured according to Langston Hughes' poem, "The Negro Speaks of Rivers," in which the speaker refers to African and American rivers symbolizing his double heritage, African and American. Marshall titles her chapters "I've Known Rivers: The James River," "I've Known Seas: The Caribbean Sea," "I've Known Oceans: The Atlantic," and, respectively, retells her journeys of self-discovery from the banks of the James River, to the Caribbean, and on to Nigeria. She bonds with certain inhabitants from the three geographic locations, in the U.S. with black American descendants of enslaved Africans, with her colonized forebears in Barbados and Grenada, and enslaved Africans in Nigeria. Her self-discovery is enhanced by accounts of her parents' immigration to America, of her father's departure for New York to join Father Devine's sect, of women hawkers and the rebellion of Bussa and Nanny Grigg in Barbados, of the Grenadian spiritual and female activist Odessa Gittens and the origin of the Big Drum/Nation Dance ritual there, and of colonialist corruption in Nigeria. While Paule Marshall's narrative of self-discovery oscillates around three axes, Gloria Naylor's narrative has two main streams, as she seeks to reconstruct the pernicious development of her paranoia. One storyline relates the onset of gradually ever increasing invasive and deleterious surveillance, most of which, as Naylor reveals in the aforementioned interview, the writer actually experienced personally. The narrative moves from an initial portrayal of Gloria Naylor as a self-assertive, successful, and prolific writer to that of a confessional, psychologically exhausted paranoiac. Fragments of this storyline intertwine with pure fiction, whereby Naylor projects an entire conspiratorial network comprised of stories about her psychologically unsound, self-indulgent, paranoiac, neurotic neighbour, Eunice, and her equally neurotic perfectionist brother, Dick Simon, who is a National Security Agency head official. Naylor also imagines those individual students that she refers to as the "Boys," her friend, C.J. Hudson, and her black New York neighbour have been recruited by the secret service.

The stories in both memoirs are told with emotional intensity, another feature common to Black American women's writing (Dandridge 2004: 4, Bell 2004: 137, Hill 2004: 263). Marshall reveals black people's fear of the federal government when she panics upon receiving a letter from the State Department $(1,6)$. She writes: "Frankly, I registered only the words 'department' and 'state,' 'State Department,' and instantly panicked, anticipating the worst. The letter just had to be bad news of some sort" (1). She had been also emotionally incensed when her Jewish editor expressed excitement about an upcoming plantation tour. She speculated angrily, "How, I wonder, would she have reacted had I announced that I was on my way to visit Dachau or Buchenwald to pay my respects to the millions 
who had perished there while doing the boogaloo and snapping my fingers" (56). She also notes the emotional expressiveness of Barbadian anti-colonialist movements, mentioning a woman who had responded with an "angry outburst" (138), criticizing a male leader, who had "assumed the crucifixion pose, arms wide, agonized face raised to Heaven" (137). She berated his posturing: "Always a big show and a lotta big talk! Always fooling up the poor, ignorant country people. He ought be shame, qui!" (138). A similarly engaging image is that of an "ancient" Nigerian woman. Marshall questions, "Were those tears on the timeless face under the gold-threaded gelee? Or simply perspiration, rivulets of perspiration, given the steam-bath heat and humidity of Lagos?" (161). More often than not, the emotions Paule Marshall projects are related to her own bonds of affinity with the marginalized and oppressed people of the three geographical contexts America, Barbados, and Africa - who contribute to the makeup of her overall tripartite identity. Gloria Naylor's narrative is similarly emotional in that she expressively portrays her characters' feelings and attitudes in two storylines. She describes her own developing paranoia in a quite epigraphic paragraph: "Paranoia is a slow poison, and a lethal one. It usually starts with small things and then grows to colour almost everything in your life. A harmless incident takes on gigantic proportions until "they" are everywhere and "it" is waiting to get you around every corner" (23). Although she attempts to stave off paranoia, she eventually comes to the conclusion that "I am in a battle for my mind" (3). While doing so, she ponders the emotional state of people connected with the secret service network, who direct their white supremacist antipathy against an innocent black woman by the intrusive unconscionable abuse of the state apparatus.

Emotional vividness enhances the literariness of Marshall's and Naylor's memoirs in that this criterion has been considered as one of the main features that distinguishes a literary text from a non-literary one. For instance, one of the defining elements of Metaphysical Poetry that T.S. Elliot particularly acknowledged was a fusion of intellect and emotions, "a direct sensuous apprehension of thought, or a recreation of thought into feeling" (1921). Furthermore, magical realism theorists define 'felt history' vis-à-vis documented or natural history. For instance, John Burt Foster, Jr. (1995: 273) contends that: "felt history refers to the eloquent gestures and images with which a character or lyric persona registers the direct pressure of events, whether enlarging and buoyant or limiting and harsh." Toni Morrison (2008: 71) considers the literary image - "a 'picture' (along with) the feelings that accompany the picture" - to be a means whereby the novelist reconstructs her characters 'interior' lives, filling in the gaps of historiographical writing and slave narratives. From the aforementioned perspectives, both theoreticians as well as artists are of the view that emotionalized representations augment textual literariness. 
Lastly, vivid and graphic, sometimes fictional, imagery enhances the literariness of both memoirs. For example, reimagining the terror of the Middle Passage and the dehumanization her ancestors suffered, Marshall envisions a slave market where,

\footnotetext{
Waiting outside would be a crowd of eager buyers, each with a long rope. Then, once the gate was opened, the 'scrambles' began, with the buyers dashing about the yard or pen or stockade, desperate to lasso and corral as many chattel as possible never mind their condition: the stench, the running sores, the caked shit. (48)
}

Another vivid image is that of the Caribbean landscape, which offers itself as a fertile ground for reimagining the past.

\begin{abstract}
Bathsheba was the name of practically every feature of the landscape (...) including the high cliff, the village adjoining the cliff (...) and even the modest hotel on top of the cliff (...) The assemblage of huge rocks was a West Indian Stonehenge, I decided, whose provenance and purpose lay open to the imagination. An earthquake or a hurricane millennia ago might have dislodged them from the "Scottish" hills and sent them hurtling down to the shoreline. Or, in a superhuman show of strength, the original Amerindian or Carib dwellers of Barbados might have placed them there to ward off all invaders from the sea. (Marshall 2009: 113-114)
\end{abstract}

Gloria Naylor, in turn, employs beautiful imagery in order to place in bold relief the ruining consequences of surveillance. The surrounding landscape is reflective of her psychological condition. First off, as an inspired, prolific, and successful novelist, she purchases a Victorian cottage on St. Helena Island, a place that appears to be an idyllic location. "There is a stillness about the place. The sandy soil under your feet, the gentle marsh breezes coming from the east, all seem to speak of eternity" (10). However, she later comes to realize that even on the island, she, as a black woman, is without sanctuary. Observing an intrusion into her house and computer, she describes the image of her devastated garden as a reflection of the creeping psychological breakdown she undergoes as the intrusive surveillance mounts.

The [tomato] plant had gone totally black as if someone had scorched it with fire. I also saw that my brussels sprouts were beginning to wither. I dug up the tomato plant and all the brussels sprouts. It was like losing a part of myself. I had worked so hard on that garden. (65)

\title{
4. Conclusion
}

In conclusion, in order to dramatize their individual experiences, Marshall and Naylor utilize their creative imaginations to portray vivid images and emotions in incorporating stories of people who they had never met personally. Naylor's 
work is more fictional in nature than Marshall's. That is the reason in all probability why her book 1996 is referred to varyingly as a novel or fictionalized memoir. Interestingly, The World Press decided to publish the work as a novel even though Naylor herself considers the work to be a "fictionalized memoir". The critic John L. Jackson, Jr. (2008: 84) explicates:

\begin{abstract}
not because she believes that any of the aforementioned details are made up or fanciful. She stands by the veracity and factuality of the devices she depicts, even going so far as to include an appendix with materials documenting other people's research on government-sponsored mind-reading techniques. Naylor only characterizes her memoir as "fictionalized" because it takes creative license with the inner lives of her tormentors, purporting to know their deepest thoughts and most hidden motivations.
\end{abstract}

Nevertheless, in both works, most of the political, cultural and historical information cited has been documented and is based upon the writers' real life experiences. These two works evidence the fact that memoir as a genre encompasses narrative strategies employed by pure fiction writers in the novels. At the same time, although they comprise myriad imagined references, the label of novel would be overgeneralizing and reductive, as the literature is based too closely upon the authors' actual experiences. For this reason, Gloria Naylor regards 1996 as a fictionalized memoir rather than a novel, notwithstanding her publisher's designation. Moreover, despite holding a number of detailed accounts of the authors' personal experiences, memoirs differ from autobiographies as William Zinsser (1998: 15) asserts: "Unlike autobiography, which moves in a dutiful line from birth to fame, memoir narrows the lens, focusing on a time in the writer's life that was unusually vivid, such as childhood or adolescence, or that was flamed by war or travel or public service or some other special circumstance." Corresponding with Zinsser's differentiation between autobiography and memoir, Marshall's memoir 'narrows the lens' by focusing on the intricacy of the writer's rediscovery of her tripartite identity, and Naylor retells an 'unusually vivid' time in her life - the experience of surveillance. Simultaneously, Marshall's and Naylor's works seem, to a certain extent, to contradict another feature that distinguishes memoir from autobiography in that "A memoir is how one remembers one's own life, while an autobiography is history, requiring research, dates, facts double-checked" (Vidal qtd. in Burke and Danielson 2014: 20). While both writers cite the significant role memory plays in the construction of their narratives, they also give diligent attention to historical accuracy as they employ the power of their imaginations. For instance, in reconstructing her journey to Barbados, Marshall writes: 
Only fragmented memories remain of the crowded disembarkation shed at Bridgetown, the capital of Barbados. However, what remains vivid in my mind is the sight of the small, resoundingly black old woman bearing down on us in a long-skirted dress that was the same blinding white as the tropical sunlight outside. (2009: 69)

The remembered image of the woman was so touching that it inspired Paule Marshall to begin historical research in Barbados, which further kindled her imagination and engendered a sense of ancestral bonding with black Caribbean women. Eventually, memory, historical acumen and imagination were interfused, reflecting in a chapter of her memoir as well as novels. Marshall writes that the remembered woman "appears, in one guise or another, in every book I've written" (70). Analogously, Gloria Naylor's narrative in 1996 is an interfusion of her memories, imagination and factual research. In an interview, she thus recalls her experience of surveillance:

I was being followed, and then I began to see the surveillance that was going past the road on my house. And so, these cars began to surveil me. People began to follow me around, and it did, it was very disturbing to think that your privacy was being violated, and for no reason that I could come up with. (Gordon 2006)

Because she found it impossible to come up with rational reasons for her subjection to surveillance, Naylor imagined the root was racial hatred. Generally, Naylor's narrative evinces major features of paranoid style i.e. "the sense of heated exaggeration, suspiciousness, and conspiratorial fantasy" (Hofstadter 1964). However, her racial perspective has effected a fictitious representation of the development of what Jackson (2008: XVI) conceptualizes as "racial paranoia: distrustful conjecture about purposeful race-based maliciousness and the "benign neglect' of racial indifference" in retelling the emotions of a surveillance target whose imagination was spurred by governmental surveillance research.

The role of creative imagination is one of the factors that enhance the literariness of Marshall's and Naylor's works by which they retell certain aspects of their racial experience. Taking into account the significant role imagination plays in composing both Triangular Road and 1996 one can deduce that these works are situated somewhere between the aforementioned concept of the fictionalized memoir of Gloria Naylor's and Lewis Turco's understanding of creative nonfiction whereby "certain nonfiction subgenres utilize many of the same 'creative writing' techniques" (1999: 112). 


\section{REFERENCES}

Bell, Bernard W. 2004. The contemporary African American novel: Its folk roots and modern literary branches. Amherst \& Boston: University of Massachusetts Press.

Burke, Abby \& Kathy Everts Danielson. 2014. Memoirs: Making sense of our own stories. Illinois Reading Council Journal 42(3). 20-25.

Cannon, Katie Geneva. 2003. Katie's canon: Womanism and the soul of the black community. New York: Continuum.

Christian, Barbara. 1985. Black feminist criticism: Perspectives on black women writers. New York: Pergamon Press.

Christian, Barbara. 1993. Naylor's Geography: Community, Class and Patriarchy in The women of Brewster Place and Linden Hills. In Henry Louis Gates, Jr. \& K. A. Appiah (eds.), Gloria Naylor: Critical perspectives past and present, 106-125. New York: Amistad Press.

Dandridge, Rita B. 2004. Black women's activism: Reading African American women's historical romances. New York: Peter Lang.

Elliot, T.S. 1921. The Metaphysical Poets. http://personal.centenary.edu/ dhavird/TSEMe taPoets.html. (accessed 10 April 2011.)

Foster, John Burt Jr. 1995. Magical realism, compensatory vision, and felt history: Classical realism transformed in The white hotel. In Lois Parkinson Zamora \& Wendy B. Faris (eds.), Magical Realism: Theory, History, Community, 267-283. Durham, N.C.: Duke University Press.

Gordon, Ed. 2006. 1996: Under the watchful eye of the government. Interview with Gloria Naylor. http://www.npr.org/templates/story/story.php?storyId=5168026 (accessed 23 January 2006.)

Hill Collins, Patricia. 2000. Black feminist thought: Knowledge, consciousness, and the politics of empowerment. New York: Routledge.

Hofstadter, Richard. 1964. The paranoid style in American politics. Harper's magazine 77-86. $\mathrm{http} / / /$ nationalism.org/patranoia/hofstadter-paranoid-style.htm. (accessed 20 January 2015.)

Jackson, John L., Jr. 2008. Racial paranoia: The unintended consequences of political correctness. New York: Basic Civitas Books.

Macmillan Information Now Encyclopedia: The African-American Experience. 1998. New York: Macmillan Publishing Company.

Marshall, Paule. 2009. Triangular road: A memoir. New York: Basic Civitas Books.

Morrison, Toni. 2008. This Site of Memory. In Carolyn C. Denard (ed.), What moves at the margin, 65-82, Jackson: University Press of Mississippi.

Matthews, Donald H. 1998. Honoring the Ancestors: An African Cultural Interpretation of Black Religions and Literature. New York: Oxford UP.

Naylor, Gloria. 2005. 1996. Chicago: The World Press.

Turco, Lewis. 1999. The book of literary terms: The genres of fiction, drama, nonfiction, literary criticism and scholarship. Hanover: UP of New England.

Zinsser, W. (ed.). 1998. Inventing the truth: The art and craft of memoir. Boston: Houghton Mifflin. 